\title{
A coprological survey of gastro-intestinal parasites of water buffaloes (Bubalus bubalis) in Kurigram district of Bangladesh
}

\author{
M. A. A. Mamun, N. Begum and M. M. H. Mondal \\ Department of Parasitology, Bangladesh Agricultural University, Mymensingh-2202, Bangladesh \\ Email: mamun.dvm@gmail.com
}

\begin{abstract}
Epidemiology of gastro-intestinal parasites of water buffaloes was investigated in Kurigram district of Bangladesh between November 2007 and October 2008 through coprological examination. A total of 236 water buffaloes were examined, among them $144(61.02 \%)$ buffaloes were found infected with one or more species of gastro-intestinal parasites. Nine species of gastro-intestinal parasites were identified, of them four species were trematodes, namely, Paramphistomum cervi (29.24\%), Fasciola gigantica (22.46\%), Schistosoma indicum (1.27\%), Schistosoma spindale $(0.85 \%)$; three species were nematodes, namely, Toxocara vitulorum $(2.54 \%)$, Strongyles (0.85\%), Strongyloides sp. $(0.42 \%)$ and two species were protozoa, namely, Eimeria sp. (3.39\%) and Balantidium coli (37.29\%). No cestode was detected. Among the gastro-intestinal parasites mixed infection was common. In this investigation, prevalence of parasites in relation to age, sex and seasonal dynamics was also studied. Significantly $(p<0.01)$ higher prevalence of gastro-intestinal parasites was observed in rainy season followed by summer and winter seasons. Males and females were almost equally (odd ratio 1.08) susceptible to gastro-intestinal parasitic infection. In the age groups, young $(<2$ to 5 years) were mostly $(p<0.01)$ susceptible to gastro-intestinal parasites. In the present study, EPG (Egg/cyst Per Gram of Feces) was also determined. The range of EPG varied from 100-5000 among the identified parasites. The results of the present investigation revealed that the prevalence of gastro-intestinal parasites in buffaloes is very common and quite severe. It is imperative that integrated strategies and measures be taken to control gastrointestinal parasitic infections in buffaloes in kurigram district and elsewhere in Bangladesh.
\end{abstract}

Keywords: Buffalo, Gastro-intestinal parasites, Kurigram district

\section{Introduction}

Bubalus bubalis (buffalo) is one of the most important species of domestic livestock as a source of dairy, meat, manure and drought power in Bangladesh. In some parts of Bangladesh, especially in the hilly areas, river basins and low lying marshy land, the farmers are more dependent on buffaloes than cattle. The working life of buffalo is longer than that of cattle, usually more than 17 years and up to 25 years of age. Because of this excellent draft and pulling capacity, buffaloes are called the living tractor of the East (Cockrill, 1968). But, scientific knowledge concerning this animal has not been commensurate with its increasing numbers and importance. The Food and Agriculture Organization (FAO, 2000) has rightly termed buffalo as an important but 'an asset undervalued'.

Buffalo diseases have been identified as one of the major factor which have disrupted the development of the industry in Asia and have caused substantial economic loss to the poor subsistent farmers in the developing countries. The parasitic diseases are not less important in buffaloes than other infectious diseases. These mainly include gastro-intestinal helminthiasis, coccidiosis, fascioliosis and mange (Griffiths, 1974). Besides other etiological factors known commonly to affect the buffalo, diverse and manifold types of "helminthosis" and "helminthiasis", resulting from different grades of infections with fluke, tapeworms, and roundworms, are responsible for marked deleterious effects which causes considerable economic losses globally to the buffalo industries and farming communities as a consequence of deaths of infected animals, reduced weight gains and the condemnation of affected organs after slaughter (Jithendran and Bhat, 1999; Asif et al., 2007). In spite of significant production losses the problem is neglected due to its chronic and insidious nature (Sanyal, 1998). Moreover, some helminths of buffaloes are also transmissible (directly or indirectly) to humans where they can cause significant clinical diseases, such as schistosomiasis and fascioliasis in a number of countries (Wang et al., 2006; Tum et al., 2007). In excess of helminths, buffaloes are suffered from various intestinal protozoan infections also (Azam et al. 2002; Nalbantoglu et al., 2008). 
In developed countries, the data on epidemiology of various gastro-intestinal parasites are published in an efficient manner as an aid to combat infections more effectively. In contrast, in developing countries, little published information exists and data on the epidemiological aspect of gastro-intestinal parasitic infections. As is the case elsewhere, infection of water buffaloes with gastro-intestinal parasites represents a significant problem which causes difficulty for the development of the water buffalo industry. However, while there have been only limited surveys of gastro-intestinal parasitic infections in water buffaloes in, little is known about the prevalence of gastro-intestinal parasites of water buffaloes in the country under present husbandry practices. In order to provide a foundation for the improved control of gastro-intestinal parasites in water buffaloes, the objective of the present investigation was to estimate the prevalence of gastro-intestinal parasites in water buffaloes in Kurigram district of Bangladesh by coprological examination.

\section{Materials and Methods}

\section{The study area}

Kurigram District (Coordinates: $25^{\circ} 45^{\prime} \mathrm{N} 89^{\circ} 40^{\prime} \mathrm{E} / 25.75^{\circ} \mathrm{N} 89.66^{\circ} \mathrm{E}$ ) with an area of 2,296.10 square $\mathrm{km}$ is located in the north-eastern region of Bangladesh along the border of India. Maximum and minimum annual average temperature of Kurigram is $32.3^{\circ} \mathrm{C}$ and $11.2^{\circ} \mathrm{C}$, respectively; in both cases it is more acute than the middle or southern part of Bangladesh. The average annual rainfall is about $3000 \mathrm{~mm}$ with heavy rainfall is usually observed during the rainy season like other parts of Bangladesh. Several rivers are flowing through the heart of this district including Brahmaputra, Dharla, Tista, Sonaburi, Jinjiram etc. with numerous chars (Char is a Bangla word and it means "island") provide unique pasture resource for the development of livestock industry including buffaloes. Moreover, buffaloes are popularly used for drought purposes in these char area because of poor transport system.

\section{Sampling and Selection of water buffaloes}

The investigation took place between November 2007 and October 2008. Two hundred and thirty six water buffaloes were selected randomly from different chars of the study area. During collection of fecal samples the age and sex of the buffaloes and seasons of the year were carefully recorded. Seasons were considered as summer (March-June), rainy (July-October) and winter (November-February).

\section{Collection and examination of faecal sample}

The faecal samples were collected directly from the rectum of the animals. Before collection, the animals were restrained properly and all possible hygienic measures including wearing of apron, hand gloves and gumboot were taken to avoid contamination. Fresh faecal samples were also collected from the ground when the animals were found in the act of defecation. About 20-25 grams of faeces were collected from each buffalo. Each sample was kept in separate polythene bag, tied carefully and numbered properly and the samples were preserved in $10 \%$ formalin. The correctly labeled and properly numbered polythene bags containing the faecal samples with all required information were brought to the laboratory and examined. The fecal samples were examined by Modified Stoll's Dilution Technique which was following for total egg/cyst count per gram of faeces (EPG) as described by Soulsby (1982).

\section{Statistical analysis}

Statistical analyses were carried out by Statistical Package for Social Science (SPSS) using F test. Odd ratio was calculated according to the formula given by Schlesselman (1982).

\section{Results and Discussion \\ Overall prevalence of gastro-intestinal parasites}

The research work indicated that, the water buffaloes were very much susceptible to gastro-intestinal parasitic infection. It was observed that, $144(61.02 \%)$ buffaloes were found infected with one or more species of gastro-intestinal parasites. Similar findings were reported by Azam et al. (2002) who revealed that $64.41 \%$ buffaloes are positive for internal parasites in Pakistan. Slightly lower prevalence was observed by Bachal et al. (2002) who recorded $47 \%$ buffaloes suffering from different types of helminths in Pakistan. Cockrill (1974) stated that the buffalo is exposed to a higher risk of infection with snail borne helminthes due to the animals propensity to seek rivers, pools or swamps for wallowing. This is true in Bangladesh context as well. 
A total of nine species of gastro-intestinal parasites (ova/eggs/cysts) were identified, representing four species of trematode, three species of nematode and two species of protozoa. No cestode was detected. Mixed infection was common. It was observed that, prevalence of B. coli. (37.29\%) was the highest whereas Strongyloides sp. infection $(0.42 \%)$ was the least. The species of parasites found, their prevalence and the intensities of infection (ranges) are given in Table 1. Among the trematodes, prevalence of Fasciola gigantica $(22.46 \%)$ and Paramphistomum cervi $(29.24 \%)$ was the highest. Islam et al. (1992) also reported an overall $18.9 \%$ F. gigantica and $29.50 \%$ Paramphistomum spp. infection by fecal sample examination in buffaloes in Bangladesh. The present finding is in agreement with the earlier findings of Hossain (1991) who recorded $24 \%$ fasciolosis in Bangladesh. Islam (1991) reported that Fasciola infection in buffaloes varies from place to place. In this study, prevalence of schistosomiasis was found negligible but Ravindran et al. (2007) reported $50 \%$ visceral schistosomiasis among buffaloes in India. This is might be due the faulty fecal sample collection and examination procedure.

Table 1. Overall prevalence of gastro-intestinal parasites of buffaloes in Kurigram, Bangladesh

\begin{tabular}{|l|c|c|c|c|}
\hline \multicolumn{1}{|c|}{ Name of parasites } & $\begin{array}{c}\text { No of animals } \\
\text { affected }(\mathrm{N}=236)\end{array}$ & Percentage $(\%)$ & \multicolumn{2}{c|}{ Egg/cyst Per Gram of Feces (EPG) } \\
\cline { 3 - 5 } & 69 & 29.24 & Range & Mean \pm SD \\
\hline Paramphistomum cervi & 53 & 22.46 & $100-500$ & $186.95 \pm 119.95$ \\
\hline F. gigantica & 3 & 1.27 & $100-100$ & $201.88 \pm 142.18$ \\
\hline S. indicum & 2 & 0.85 & $100-100$ & $100.00 \pm 0.00$ \\
\hline S. spindale & 6 & 2.54 & $100-200$ & $100.00 \pm 0.00$ \\
\hline T. vitulorum & 2 & 0.85 & $100-100$ & $100.67 \pm 40.83$ \\
\hline Strongyles & 1 & 0.42 & $100-100$ & $100.00 \pm 0.00$ \\
\hline Strongyloides sp. & 88 & 37.29 & $100-5000$ & $452.27 \pm 359.22$ \\
\hline B. coli & 8 & 3.39 & $100-300$ & $250.00 \pm 130.93$ \\
\hline Eimeria sp. & $144^{*}$ & 61.02 & $100-5000$ & $178.57 \pm 88.12$ \\
\hline \multicolumn{1}{|c|}{ Total } & & & \\
\hline
\end{tabular}

* = Total no. of animals affected is less than the summation of individual infection because same animal was infected by more than one type of gastro-intestinal parasites

$\mathrm{N}=$ Total animals examined

In the present study, the numbers of nematode species found in buffaloes are less than that reported by other scientists from different parts of the world (Condoleol et al., 2007), which may due to the difference in the habitat and physiological conditions of the buffaloes and also the use of anthelmintics in recent years.

In this experiment, no cestode was detected which supported the findings of Azam et al. (2002) and Bachal et al. (2002). This is not surprising because cestodes of buffaloes are rare in recent years (Liu et al., 2009) since buffaloes are usually raised in animal houses and seldom accessible to intermediate hosts of cestodes. Azam et al. (2002) reported that $72 \%$ of the buffalo calves are suffered from intestinal protozoan infection in Pakistan which is much higher than the present finding. Nalbantoglu et al. (2008) reported $75 \%$ of water buffaloes are suffered from different Eimeria spp. in Turkey. The variations among the findings might be due to the difference in the sample size, selection of samples, techniques of sample collection, period and place of study, environmental factors, breed of the buffaloes etc.

\section{Age related prevalence of gastro-intestinal parasites}

It was revealed that, age of the buffaloes had a significant $(p<0.01)$ effect on gastro-intestinal parasitic infection. Young buffaloes $(65.85 \%)$ were more susceptible $(p<0.01)$ to infection than calves $(63.16 \%)$ and adult buffaloes (59.66\%). Calculated odd ratio implied that young buffaloes were 1.30 and 1.12 times more susceptible to infection than adult buffaloes and calves, respectively. On the other hand, calves and adult buffaloes were almost equally (odd ratio 1.16) susceptible to gastro-intestinal parasitic infection (Table 2). The present finding is in agreement with the earlier report of Azhar et al. (2002) who noticed higher infection rate in buffaloes aged $>2$ years of age. Asif et al. (2007) also reported the higher prevalence of helminths infection in young buffaloes compared to adults in Pakistan. But the present 
finding is in contrast to the previous reports of Alim (1997) who observed that infection rate of fasciolosis increased with the increase of age. Baily (1971) also suggested that the fasciolosis is not as self limiting in the buffaloes as this in the cattle. It is very difficult to explain exactly the frequent occurrence of gastrointestinal parasitic infection in young buffaloes. But it may be assumed that young buffaloes got more access to pasture land than the calves to have the infection. On the other hand, adults developed immunity with the increase of age, so susceptibility decreased with increase of age.

Table 2.Age related prevalence of gastro-intestinal parasites of buffaloes in Kurigram, Bangladesh

\begin{tabular}{|c|c|c|c|c|c|c|}
\hline \multirow[t]{2}{*}{ Age } & \multirow[t]{2}{*}{$\begin{array}{l}\text { Name of parasites } \\
\text { recovered }\end{array}$} & \multirow{2}{*}{$\begin{array}{c}\text { No. of } \\
\text { animals } \\
\text { affected }\end{array}$} & \multirow[t]{2}{*}{$\begin{array}{c}\text { Percentage } \\
(\%)\end{array}$} & \multicolumn{2}{|c|}{$\begin{array}{c}\text { Egg/cyst Per Gram of Feces } \\
\text { (EPG) }\end{array}$} & \multirow[t]{2}{*}{ Odds ratio } \\
\hline & & & & Range & Mean \pm SD & \\
\hline \multirow{6}{*}{$\begin{array}{c}\text { Buffalo } \\
\text { Calves (0.5- } \\
\text { 2years) } \\
n=19\end{array}$} & F. gigantica & 4 & 22.22 & $100-200$ & $125.00 \pm 50.00$ & \multirow{6}{*}{$\begin{array}{c}\text { Young vs } \\
\text { Calves = } \\
1.12\end{array}$} \\
\hline & Paramphistomum cervi & 2 & 11.11 & $100-400$ & $193.33 \pm 138.70$ & \\
\hline & T. vitulorum & 3 & 16.67 & $100-200$ & $133.33 \pm 57.74$ & \\
\hline & B. coli & 7 & 38.89 & $100-900$ & $347.06 \pm 264.85$ & \\
\hline & Eimeria sp. & 1 & 5.56 & $500-0.00$ & $500 \pm 0.00$ & \\
\hline & Subtotal= & $12^{*}$ & 63.16 & $100-900$ & $259.74 \pm 102.26$ & \\
\hline \multirow{8}{*}{$\begin{array}{c}\text { Young }(>2-5 \\
\text { years) } \\
n=41\end{array}$} & Paramphistomum cervi & 15 & 36.59 & $100-500$ & $193.33 \pm 138.70$ & \multirow{8}{*}{$\begin{array}{c}\text { Young vs } \\
\text { Adult = } \\
1.30\end{array}$} \\
\hline & F. gigantica & 7 & 17.07 & $100-1400$ & $300 \pm 286.48$ & \\
\hline & S.indicum & 1 & 2.44 & $100-100$ & $100.00 \pm 0.00$ & \\
\hline & S.spindale & 2 & 4.88 & $100-100$ & $100.00 \pm 0.00$ & \\
\hline & T. vitulorum & 1 & 2.44 & $100-100$ & $100.00 \pm 0.00$ & \\
\hline & B. coli & 17 & 41.46 & $100-1000$ & $347.06 \pm 264.85$ & \\
\hline & Eimeria sp. & 2 & 4.88 & $100-200$ & $150.00 \pm 70.71$ & \\
\hline & Subtotal= & $27^{*}$ & 65.85 & $100-1400$ & $184.34 \pm 108.68$ & \\
\hline \multirow{9}{*}{$\begin{array}{c}\text { Adult }(>5 \\
\text { years) } \\
n=176\end{array}$} & Paramphistomum cervi & 52 & 29.38 & $100-500$ & $193.33 \pm 138.70$ & \multirow{9}{*}{$\begin{array}{c}\text { Calves vs } \\
\text { Adult }= \\
1.16\end{array}$} \\
\hline & F. gigantica & 42 & 23.73 & $100-1200$ & $193.04 \pm 192.85$ & \\
\hline & S. indicum & 2 & 1.13 & $100-100$ & $100.00 \pm 0.00$ & \\
\hline & T. vitulorum & 2 & 1.13 & $100-100$ & $100.00 \pm 0.00$ & \\
\hline & Strongyles & 2 & 1.13 & $100-100$ & $100 \pm 0.00$ & \\
\hline & Strongyloides sp. & 1 & 0.56 & $100-100$ & $100 \pm 0.00$ & \\
\hline & B. coli & 63 & 35.59 & $100-5000$ & $347.06 \pm 264.85$ & \\
\hline & Eimeria sp. & 5 & 2.82 & $100-300$ & $150.00 \pm 70.71$ & \\
\hline & Subtotal= & $105^{*}$ & 59.66 & $100-5000$ & $160.43 \pm 83.39$ & \\
\hline \multicolumn{3}{|c|}{ Level of significance } & \multicolumn{4}{|c|}{$(0.0002)^{\star *}$} \\
\hline
\end{tabular}

$\mathrm{n}=$ Total animals examined

* = Total no. of animals affected is less than the summation of individual infection because same animal was infected by more than one type of gastro-intestinal parasites

** $=$ Means $\mathrm{p}<0.01$

\section{Sex related prevalence of gastro-intestinal parasites}

There was significant $(p<0.01)$ difference in the rate of gastro-intestinal parasitic infection in between the male and female buffaloes. It was observed that, the prevalence of gastro-intestinal parasites was slightly higher in male $(61.34 \%)$ than in female buffaloes (59.52\%). Male buffaloes were 1.08 times more vulnerable to gastro-intestinal parasitic infection than females (Table 3). Asif et al. (2007) also reported the higher prevalence of gastro-intestinal parasites in males than females for buffaloes in Pakistan. But this report is in contrast to the previous report of Bachal et al. (2002) who reported a slightly higher prevalence $(48.30 \%)$ of helminths in female buffalo calves than in male (45.12\%). Alim (1997) also reported that females (52.65\%) are more susceptible to Fasciola infection than male $(47.76 \%)$. On the other hand, Azhar et al. (2002) noticed that buffaloes of either sex are equally affected. This disparity among the findings can not be explained exactly but it might be assumed that disparity of sample among the male and female may be associated with this. Moreover, male buffaloes are popularly used for drought purposes leading to stress which predisposes the infection. 
Table 3. Sex related prevalence of gastro-intestinal parasites of buffaloes in Kurigram, Bangladesh

\begin{tabular}{|c|c|c|c|c|c|c|}
\hline \multirow[t]{2}{*}{ Parameters } & \multirow[t]{2}{*}{ Name of parasites } & \multirow{2}{*}{$\begin{array}{l}\text { No. of } \\
\text { animals } \\
\text { affected }\end{array}$} & \multirow[t]{2}{*}{$\begin{array}{c}\text { Percentage } \\
\%\end{array}$} & \multicolumn{2}{|c|}{$\begin{array}{l}\text { Egg/cyst Per Gram of Feces } \\
\text { (EPG) }\end{array}$} & \multirow[t]{2}{*}{ Odds ratio } \\
\hline & & & & Range & Mean $\pm S D$ & \\
\hline \multirow{9}{*}{$\begin{array}{c}\text { Male } \\
n=194\end{array}$} & Paramphistomum cervi & 57 & 29.38 & $100-500$ & $119.94 \pm 116.96$ & \multirow{18}{*}{$\begin{array}{l}\text { Male vs } \\
\text { Female }= \\
1.08\end{array}$} \\
\hline & F. gigantica & 47 & 24.23 & $100-1300$ & $242.18 \pm 201.89$ & \\
\hline & S. indicum & 2 & 1.03 & $100-100$ & $100.00 \pm 0.00$ & \\
\hline & T. vitulorum & 4 & 2.06 & $100-200$ & $40.82 \pm 116.67$ & \\
\hline & Strongyles & 2 & 1.03 & $100-100$ & $100.00 \pm 0.00$ & \\
\hline & Strongyloides sp. & 1 & 0.52 & $100-100$ & $100.00 \pm 0.00$ & \\
\hline & B. coli & 72 & 37.11 & $100-5000$ & $622.60 \pm 454.02$ & \\
\hline & Eimeria sp. & 5 & 2.58 & $100-500$ & $130.93 \pm 75.00$ & \\
\hline & Subtotal= & $119 *$ & 61.34 & $100-5000$ & $182.06 \pm 120.56$ & \\
\hline \multirow{9}{*}{$\begin{array}{c}\text { Female } \\
n=42\end{array}$} & Paramphistomum cervi & $\overline{12}$ & 28.57 & $100-500$ & $188.06 \pm 121.26$ & \\
\hline & F. gigantica & 6 & 14.29 & $100-1400$ & $206.00 \pm 148.00$ & \\
\hline & S. spindale & 2 & 4.76 & $100-100$ & $100.00 \pm 0.00$ & \\
\hline & S. indicum & 1 & 2.38 & $100-100$ & $100.00 \pm 0.00$ & \\
\hline & T. vitulorum & 2 & 4.76 & $100-200$ & $116.67 \pm 40.82$ & \\
\hline & Strongyloides sp. & 1 & 2.38 & $100-100$ & $100.00 \pm 0.00$ & \\
\hline & B.coli & 15 & 35.71 & $100-5000$ & $450.00 \pm 431.03$ & \\
\hline & Eimeria sp. & 3 & 7.14 & $100-500$ & $250.00 \pm 130.93$ & \\
\hline & Subtotal= & $25^{*}$ & 59.52 & $100-5000$ & $178.97 \pm 96.89$ & \\
\hline \multicolumn{4}{|c|}{ Level of significance } & \multicolumn{3}{|c|}{$(0.0001)^{\star \star}$} \\
\hline $\begin{array}{l}\mathrm{n}= \\
*= \\
* *=\end{array}$ & \multicolumn{6}{|c|}{$\begin{array}{l}\text { Total animals examined } \\
\text { Total no. of animals affected is less than the summation of individual infection because } \\
\text { same animal was infected by more than one type of gastro-intestinal parasites }\end{array}$} \\
\hline
\end{tabular}

\section{Seasonal prevalence of gastro-intestinal parasites}

Seasonal fluctuation of the year had a significant $(p<0.01)$ effect on the prevalence of gastro-intestinal parasitic infection in buffaloes. A relatively higher infection with gastro-intestinal parasites were observed in rainy season $(71.70 \%)$, followed by summer $(58.90 \%)$ and winter $(52.27 \%)$ seasons. In this study, it was also revealed that buffaloes were 1.77 and 1.89 times more susceptible to gastro-intestinal parasitic infection in rainy season than summer and winter seasons, respectively. On the other hand, in summer and winter season buffaloes were almost equally (odds ratio 1.07) prone to gastro-intestinal parasitic infection (Table 4). The present finding is much higher than the previous reports of Azhar et al. (2002) who reported the highest $(24.0 \%)$ seasonal prevalence in all types of buffaloes during autumn, followed by spring $(20.0 \%)$, winter $(13.0 \%)$, while the lowest $(9.0 \%)$ was recorded during summer in Pakistan. The present finding is in agreement with the earlier reports of Islam (1989) who reported the prevalence of fasciolosis by feces examination is $28.6 \%, 18.7 \%$ and $11.7 \%$, respectively, during winter, summer and rainy season. But the author reported the much higher prevalence of Strongyloides sp. during winter $(17.1 \%)$, summer $(20 \%)$ and in rainy season $(8.3 \%)$. The contrast in between the present and earlier findings can be explained by the fact of variation in the geographical location of the experimental area and also the methods of study. Moreover, in this study, year was divided into three seasons but in other parts of the world there were four seasons. So, this difference in the division of seasons had made some over lapping of months and seasons. Therefore, that might have created some contradictions. However, the highest prevalence in rainy season may be due to high humidity and heavy rainfall which favors the growth and multiplication of parasites as well as their vectors. 
Table 4. Seasonal prevalence of gastro-intestinal parasites of buffaloes in Kurigram, Bangladesh

\begin{tabular}{|c|c|c|c|c|c|c|}
\hline \multirow[t]{2}{*}{ Season } & \multirow[t]{2}{*}{ Name of parasite } & \multirow{2}{*}{$\begin{array}{c}\text { No. of } \\
\text { animals } \\
\text { affected }\end{array}$} & \multirow[t]{2}{*}{$\begin{array}{c}\text { Percentage } \\
(\%)\end{array}$} & \multicolumn{2}{|c|}{$\begin{array}{l}\text { Egg/cyst Per Gram of Feces } \\
\text { (EPG) }\end{array}$} & \multirow[t]{2}{*}{$\begin{array}{l}\text { Odds } \\
\text { ratio }\end{array}$} \\
\hline & & & & Range & Mean \pm SD & \\
\hline \multirow{8}{*}{$\begin{array}{l}\text { Rainy } \\
n=53\end{array}$} & Paramphistomum cervi & 24 & 45.28 & $100-500$ & $186.95 \pm 119.94$ & \multirow{8}{*}{$\begin{array}{c}\text { Rainy vs } \\
\text { Summer } \\
=1.77\end{array}$} \\
\hline & F. gigantica & 7 & 13.21 & $100-1200$ & $201.88 \pm 112.18$ & \\
\hline & S. spindale & 2 & 3.77 & $100-100$ & $100.00 \pm 0.00$ & \\
\hline & S. indicum & 1 & 1.89 & $100-100$ & $100.00 \pm 0.00$ & \\
\hline & T. vitulorum & 1 & 1.89 & $100-200$ & $116.67 \pm 40.82$ & \\
\hline & Strongyloides sp. & 1 & 1.89 & $100-100$ & $100.00 \pm 0.00$ & \\
\hline & B. coli & 29 & 54.72 & $100-5000$ & $452.27 \pm 405.63$ & \\
\hline & Subtotal= & 38* & 71.70 & $100-5000$ & $192.96 \pm 113.09$ & \\
\hline \multirow{8}{*}{$\begin{array}{c}\text { Summer } \\
n=73\end{array}$} & Paramphistomum cervi & 21 & 28.77 & $100-500$ & $175.56 \pm 120.90$ & \multirow{8}{*}{$\begin{array}{l}\text { Summer } \\
\text { vs Winter } \\
=1.07\end{array}$} \\
\hline & F. gigantica & 19 & 26.03 & $100-1200$ & $217.39 \pm 256.74$ & \\
\hline & S. indicum & 1 & 1.37 & $100-100$ & $100.00 \pm 0.00$ & \\
\hline & T. vitulorum & 2 & 2.74 & $100-200$ & $120.00 \pm 44.72$ & \\
\hline & Strongyles & 1 & 1.37 & $100-100$ & $100.00 \pm 0.00$ & \\
\hline & B. coli & 22 & 30.14 & $100-5000$ & $471.18 \pm 332.51$ & \\
\hline & Eimeria sp. & 4 & 5.48 & $100-300$ & $250.00 \pm 130.93$ & \\
\hline & Subtotal= & $43^{*}$ & 58.90 & $100-5000$ & $204.87 \pm 126.54$ & \\
\hline \multirow{8}{*}{$\begin{array}{l}\text { Winter } \\
n=110\end{array}$} & F. gigantica & 27 & 24.55 & $100-1200$ & $192.59 \pm 123.80$ & \multirow{8}{*}{$\begin{array}{c}\text { Rainy vs } \\
\text { Winter }= \\
1.89\end{array}$} \\
\hline & Paramphistomum cervi & 24 & 21.82 & $100-500$ & $179.16 \pm 128.47$ & \\
\hline & S. spindale & 1 & 0.91 & $100-100$ & $100.00 \pm 0.00$ & \\
\hline & T. vitulorum & 3 & 2.73 & $100-200$ & $133.33 \pm 57.74$ & \\
\hline & Strongyles & 1 & 0.91 & $100-100$ & $100.00 \pm 0.00$ & \\
\hline & B. coli & 37 & 33.64 & $100-5000$ & $302.70 \pm 236.27$ & \\
\hline & Eimeria sp. & 4 & 3.64 & $100-300$ & $275.00 \pm 170.78$ & \\
\hline & Subtotal & $63^{*}$ & 57.27 & $100-5000$ & $183.21 \pm 102.44$ & \\
\hline \multicolumn{4}{|c|}{ Level of significance } & \multicolumn{3}{|c|}{$(0.0021)^{\star *}$} \\
\hline
\end{tabular}

$\mathrm{n}=$ Total animals examined

* = Total no. of animals affected is less than the summation of individual infection because same animal was infected by more than one type of gastro-intestinal parasites

** $=$ Means $p<0.01$

The results of the present investigation indicated that the prevalence of gastro-intestinal parasites in water buffaloes is very common and quite severe irrespective of age and sex of the buffaloes and seasons of the year. It is imperative that integrated strategies and measures be taken to control gastrointestinal parasitic infections in buffaloes in kurigram district and elsewhere in Bangladesh.

\section{References}

Alim, M.A. 1997. Some epidemio-pathological aspects of fascioliasis in buffaloes in Bangladesh. MS Thesis, Submitted to the Department of Parasitology, Bangladesh Agricultural University, Mymensingh.

Asif, R.M., Iqbal, Z., Jabbar, A. and Yaseen, M. 2007. Point prevalence of gastrointestinal helminthiasis in ruminants in southern Punjab, Pakistan. Journal of Helminthology, 81(3): 323-328.

Azam, M., Siddiqui, M.M. and Habib, G. 2002. Prevalence of parasitic infection in buffalo calves in Khadagzai, district Dir. Pakistan Veterinary Journal, 22(2): 87-90.

Azhar, M., Chaudhry, S.H., Tanveer, A. and Haji, A.H. 2002. Epidemiology of fasciolosis in buffaloes under different managemental conditions. Veterinarski Arhiv, 72 (4): 221-228. 
Bachal, B., Sharif, P., Rahamatullah, R. and Aijaz, H.S. 2002. Prevalence of gastro-intestinal helminths in Buffalo calves. Journal of Biological Sciences, 2(1): 43-45.

Baily, W.S. 1971. Report to the Government of the Philippines on a Pilot project for the control of liver fluke on carabaos in sorsogon province. Food and Agriculture Organization, Rome, United National Development Programme, Report No. TA 2995.

Cockrill, W.R. 1974. The working buffalo. In: The Husbandry and Health of the Domes tic Buffalo, edited by W.R. Cockrill. Food and Agriculture Organization of the United Nations, Rome, Italy.

Cockrill, W.R. 1968. Key animals in Asia's economy. Span, 9: 12-15.

Condoleol, R.U., Veneziano, V., Bruni1, G. and Cringoli, G. 2007. Distribution of helminths in buffalo farms from central Italy. Italian Journal of Animal Science, 6(2): 920-922.

FAO, 2000. Water Buffalo: an Asset Undervalued, pp.1-6. FAO Regional Office for Asia and the Pacific, Bangkok, Thailand. http://www.aphca.org/publications/files/w_buffalo.pdf

Griffiths, R.B. 1974. Parasites and Parasitic diseases. In: The Husbandry and Health of the Domes tic Buffalo, edited by W. R. Cockrill. Food and Agriculture Organization of the United Nations, Rome, Italy. pp. 236-275.

Hossain, M.I. 1991. A survey on the disease of domestic water buffaloes at Kanihari (Senbari) Union of Mymensingh district in Bangladesh. Proceedings of the workshop on Bangladesh Agricultural University Research Progress. pp. 344-347.

Islam, F.M.S. 1989. Incidence of parasites of buffaloes in some areas of Bangladesh. MS thesis, Submitted to the Department of Parasitology, Bangladesh Agricultural University, Mymensingh.

Islam, F.M.S., Rahman, M.H. and Chowdhury, S.M. 1992. Prevalence of Parasites of Water Buffaloes in Bangladesh. Asian Australasian Journal of Animal Sciences, 5(4): 601-604.

Islam, K.S. 1991. Studies on the Epidemiology of Fasciolosis in Bangladesh. Annual Report (BLRI) Component). From November 1988 to June 1991. Presented at BARC Auditorium, October-1991.

Jithendran, K.P. and Bhat, T.K. 1999. Epidemiology of parasites in dairy animals in the North West Humid Himalayan Region of India with particular reference to gastrointestinal nematodes. Tropical Animal Health and Production, 31(4): 205-214.

Liu, Y., Li, F., Liu, W., Dai, R.S. and Zhu, X.Q. 2009. Prevalence of helminths in water buffaloes in Hunan Province, China. Tropical Animal Health and Production, 41: 543-546.

Nalbantoglu, S., Sari1, B., Cicek, H. and Karaer, Z. 2008. Prevalence of coccidian species in the water buffalo (Bubalus bubalis) in the Province of Afyon, Turkey. Acta Veterinarian Brno, 77: 111-116.

Ravindran, R., Lakshmanan, B., Ravishankar, C. and Subramanian, H. 2007. Visceral schistosomiasis among domestic ruminants slaughtered in Wayanad, South India. Southeast Asian Journal of Tropical Medicine and Public Health, 38(6): 8-10.

Sanyal, P.K. 1998. Integrated gastrointestinal parasite management in dairy animals in Gujarat by self medication. Journal of Veterinary Parasitology, 12: 17-20.

Schlesselman, J.J. 1982. Case-Control Studies. $1^{\text {st }}$ edition, Oxford University Press, New York, pp. 174-177.

Soulsby, E.J.L. 1982. Helminths, Arthropod and Protozoa of Domesticated Animals, $7^{\text {th }}$ edition, Bailliere Tindal and Cassell Ltd., London, pp. 35-740.

Tum, S., Puotinen, M.L., Skerratt, L.F., Chan, B., and Sothoeun, S. 2007. Validation of a geographic information system model for mapping the risk of fasciolosis in cattle and buffaloes in Cambodia. Veterinary Parasitology, 143: 364-367.

Wang, T., Zhang, S., Wu, W., Zhang, G., Lu, D., Ornbjerg, N. and Johansen, M.V. 2006. Treatment and reinfection of water buffaloes and cattle infected with Schistosoma japonicum in Yangtze River Valley, Anhui province, China. Journal of Parasitology, 92: 1088-1091. 